\title{
Development of the Vertebral Column and Caudal Skeleton in Prochilodus lineatus Larvae under Laboratory Conditions
}

\author{
Desarrollo de la Columna Vertebral y del Esqueleto Caudal en Larvas \\ de Prochilodus lineatus en Condiciones de Larvicultura Intensiva
}

\author{
David Roque Hernández*; Carlos Olivera*; Juan José Santinón*; Federico José Ruiz Diaz* \& Sebastián Sánchez*
}

\begin{abstract}
HERNÁNDEZ, D. R.; OLIVERA, C.; SANTINÓN, J. J.; RUIZ DIAZ. F. J. \& SÁNCHEZ, S. Development of the vertebral column and caudal skeleton in Prochilodus lineatus larvae under laboratory conditions. Int. J. Morphol., 34(1):143-148, 2016.

SUMMARY: For successful fish larviculture thorough studies describing the development of fish in different morphological aspects are required, as they are crucial for larval survival and growth. The present study described in Prochilodus lineatus larvae the osteological development of the vertebral column and caudal skeleton 30 days after hatching (dah). Larvae were obtained by artificial induction of adults. The beginning of formation of the spine occurs between 10 to 12 dah (8.3 mm standard length, SL) simultaneously to the first neural and hemal processes and the pre-caudal vertebral bodies. The ossification of the vertebral column occurred in craniocaudal direction and was completed at 28 dah $(22.6 \mathrm{~mm} \mathrm{SL})$. The development of the caudal skeleton elements started between 6 and 8 dah with the formation of the hypurals $(\mathrm{H})$, the parahipural $(\mathrm{PH})$ and the primary and secondary caudal rays. $\mathrm{H} 1$ to $\mathrm{H} 3$ were formed as cartilaginous primordia on the ventral side of the distal portion of the notochord, while the $\mathrm{PH}$ and $\mathrm{H} 4$ to $\mathrm{H} 6$ were formed subsequently. The first rays of the caudal fin were observed in correspondence with the formation of $\mathrm{H} 2$ and $\mathrm{H} \mathrm{3}$, while complete formation of the caudal fin was observed at 28 dah. The epurals, three in number, were evident as cartilaginous elements located both dorsal and distal in the notochord. Central ural complex (CUC) was formed by the fusion of three structures, the center preural 1 and urals 1 and 2 . Development of the vertebral column and the caudal skeleton in P. lineatus larvae showed similar patterns to those described for other teleosts.
\end{abstract}

KEY WORDS: Prochilodus lineatus; Larviculture; Osteological development.

\section{INTRODUCTION}

In fish with indirect ontogeny, the larval period extends from the beginning of notochord flexion until the complete formation of the fins elements (Balon, 1984; Kendall et al., 1984). During this period, rapid and intense tissue differentiation processes occur, producing changes in the shape and structure of the larvae in order to move forward to the juvenile stage (Kendall et al.).

In natural environments, the larvae can be affected by several factors, among which starvation or predations appear as the main causes that regulate the survival within this period (Bailey \& Houde, 1989). Thus, fish present high fertility allowing them to compensate the high mortality observed during the larval period (Dahlberg, 1979). According to Kendall et al., the survival chance of larvae increases along with the age as they acquire a greater ability to search and capture their preys. Similarly, several authors suggest that mortality is higher when larvae suffered some alteration during development, which adversely affects the growth, feeding, locomotion and vulnerability (Koumoundouros et al., 2001; Lewis \& Lall, 2006; Lall \& Lewis-McCrea, 2007).

In fish farming, it is common to find survival rates higher than those reported in natural environments (Woynarovich \& Horváth, 1983). However, fish culture usually presents a high percentage of individuals with morphological alterations (Koumoundouros et al., 2001; Lewis \& Lall). In this sense, knowledge of the morphological aspects of skeletal development provides valuable information to prevent earlier the incidences of malformations in farmed fishes (Çoban et al., 2009).

The genus Prochilodus is widely distributed in Latin America and its species are of great commercial importance to the region (Welcomme, 1985). Regarding the need to diversify the species for aquaculture, Prochilodus lineatus presents a great productive potential, with excellent perfor- 
mance in culture, highlighting the fast growth and good use of low quality foods (Croux, 1992). Several studies were performed on the histology of the digestive tract (Domitrovic, 1983), reproduction (Croux; Hainfellner et al., 2012), embryonic development (Botta et al., 2010) and growth (Furuya et al., 1999). On the other hand, studies on abundance as part of ichthyoplankton were also carried out in relation to the growth chronology from yolk larvae stage to juvenile (Sverlij et al., 1993; Fuentes, 1998). However, none of these papers describes the skeletal development of Prochilodus species. The present study describes for the first time the osteological development process concerning vertebral column and caudal skeleton structures in $P$. lineatus larvae reared under controlled conditions and fed with artificial diet.

\section{MATERIAL AND METHOD}

This work was carried out in the experimental aquaculture facilities of the Northeast Institute of Ichthyology (INICNE), Faculty of Veterinary Sciences-UNNE (Corrientes, Argentina). P. lineatus larvae were obtained by artificial induction of adult individuals with pituitary extract from the same species, according with the protocol proposed by González et al. (2010). After hatching, larvae were placed in $60 \mathrm{~L}$ cages at a density of 30 larvae $\mathrm{L}^{-1}$ and were fed twice daily with commercial food ( $42 \%$ crude protein) finely ground and sieved according to the mouth opening of larvae. During the sampling period the water quality of cages presented the following averages values: $26.7^{\circ} \mathrm{C}, \mathrm{pH} \mathrm{7.0}$, $6.0 \mathrm{mg} \mathrm{L}^{-1}$ of dissolved oxygen, and conductivity 129.43 $\mathrm{mS} \mathrm{cm}{ }^{-1}$. The water temperature data were used to calculate the cumulative thermal units $\left(\mathrm{CTU}\right.$ or ${ }^{\circ} \mathrm{C}$ day $\left.^{-1}\right)$.

Ten larvae were daily collected until 30 dah. Samples were slaughtered with an overdose of benzocaine $0.02 \%$ before being fixed in $10 \%$ formalin solution. Staining for bone and cartilage observation was carried out using the method described by Taylor \& Van Dyke (1985) with some modifications. All specimens were stained for bone with alizarin red S stain (stock solution: $1 \%$ Alizarin red in $1 \%$ $\mathrm{KOH})$, and for cartilage with alcian blue $8 \mathrm{GX}(0.02 \%$ in 70 $\%$ alcohol and $30 \%$ glacial acetic acid) but previously macerated using a $3 \%$ aqueous solution of $\mathrm{KOH}$ (potassium hydroxide). Then, they were preserved in pure glycerin. The time of staining exposure was related to the size of the specimens.

Larvae measuring and vertebrae counting were performed under LEICA DM500 microscope equipped with a LEICA ICC50 digital camera and KYOWA stereoscopic magnifier model SDZ coupled to a Sony digital camera. In order to understand the ontogeny of P. lineatus, we analyzed the measurements of morphological characteristics observed under microscope: notochord length (NL), from the tip of the snout to the tip of the notochord on small larvae, prior to flexion; standard length (SL), from the tip of the snout to the base of caudal complex on larger larvae, in which flexion of notochord had occurred. Larval notochord flexion and also nomenclature proposed by Kendall et al., was used throughout this article. Finally, the vertebrae counting, except for the Weber apparatus was performed.

\section{RESULTS}

In the present study, the osteological development pattern did not show variations between individuals. However, it was found that development stages of cartilage or bone were more related to the length than to the age of $P$. lineatus larvae.

Vertebral Column and Associated Bones. During the first 4 dah and with $5.2 \mathrm{~mm}$ of NL, larvae were lacked of cartilaginous or bony structures and presented a straight notochord throughout its length (Fig. 1a). The first cartilaginous structures to appear were the neural and hemal spines between 10 and 12 dah ( $8.3 \mathrm{~mm} \mathrm{SL}$ ) (Fig. 1b), in the anterior third of the vertebral column (Table I). The neural spines consisted of two rod-like structures, one on the right and one on the left laterodorsal sides of the notochord, while the hemal archs consisted of two small cartilaginous structures on the right and left lateroventral sides of the notochord. The development of these structures exhibited a progressive posterior direction, and the ossification process was observed between 15 to 18 dah (Fig. 1c).

Between the 9th and 10th dah (7.8 mm SL), the first vertebral centrum (VC) that showed a slight ossification were those corresponding to the pre-caudal region of the vertebral column (Fig. 1b and 1c), and ossification process began without a pre-cartilaginous mold. Complete vertebral column ossification occurred at 28 dah (22.6 mm SL), consisting of 23-25 pre-caudal vertebrae and 12 to 13 caudal vertebrae (Fig. 1g).

Caudal Fin Complex. The caudal skeleton development occurred between 6 and 8 dah in pre-flexion larvae. The formation of the hypurals (H) 1, 2 and 3 began as cartilaginous primordia on the ventral side of the distal portion of the notochord (Fig. 1d). Then, a cartilaginous mass corresponding to the parahipural ( $\mathrm{PH})$ element was evident between 9 and 11 dah ( $8.05 \mathrm{~mm} \mathrm{SL})$, consistent with a slight 

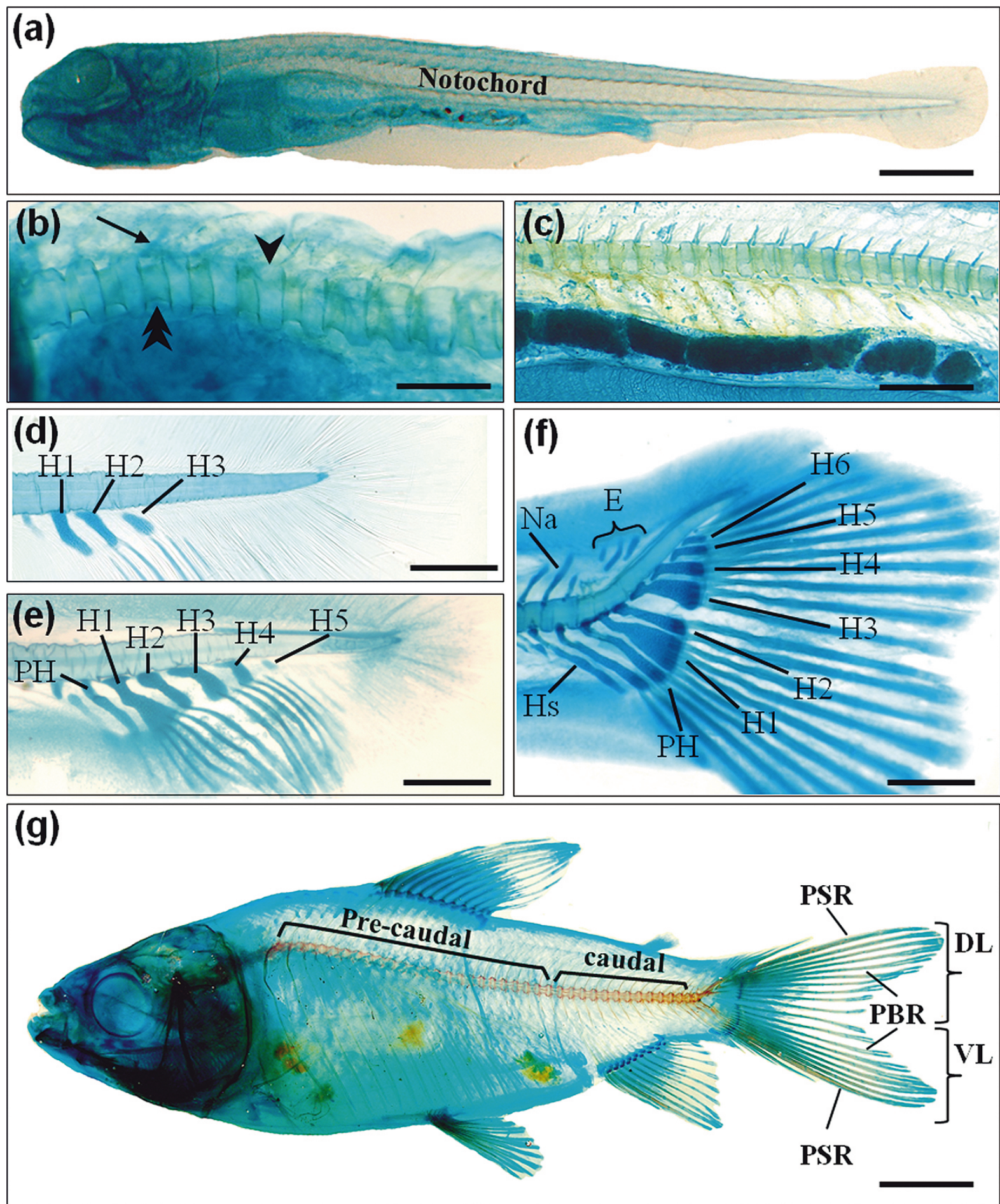

Fig. 1. Different stages of the osteological development of the vertebral column in $P$. lineatus larvae. a) Larva in pre-flexion stage (4 dah). Bar= $0.5 \mathrm{~mm}$. b) Larvae (10 dah). Onset and progress of the vertebral centrum (double arrowhead) and neural spines (arrow) ossification observed between the notochord (arrowhead). Bar $=0.5 \mathrm{~mm}$. c) Incipient ossification of the vertebral centrum and spines in 18 dah larvae. Bar $=0.3 \mathrm{~mm}$. d) The beginning of flexion stage larvae with the first three rudiments corresponding to the hypural cartilages. Bar $=0.25 \mathrm{~mm}$. e) Flexion stage larvae. Bar= $0.3 \mathrm{~mm}$. f) Post-flexion stage larvae. Bar $=0.3 \mathrm{~mm}$. g) Larva at the end of the post-flexion stage with complete ossification ( $28 \mathrm{dah})$. Bar= $3 \mathrm{~mm}$. E, epurals; Hs, hemal spines; Na, neural arches; H, hypurals; DL, dorsal lobe; VL, ventral lobe; PH, parahipural; PBR, principal branched rays; PSR, principal simple rays. 
Table I. Mean notochordal length (1-4 dah) and standard length (6-30 dah), cumulative thermal units (CTU) and developmental stage (DS) of P. lineatus larvae reared under controlled conditions.

\begin{tabular}{lccc}
\hline & \multicolumn{3}{c}{ Measured parameters } \\
\cline { 2 - 4 } Days (dah) & ${\text { CTU }\left({ }^{\circ} \mathbf{C ~} \text { day }^{-1}\right)}$ & Length \pm SD $(\mathbf{m m})$ & DS \\
\hline 1 & 26.5 & $4.7 \pm 0.07$ & Vitelline larvae \\
4 & 106.7 & $5.2 \pm 0.08$ & Pre-flexion \\
6 & 159.0 & $5.9 \pm 0.19$ & Onset-flexion \\
15 & 399.1 & $8.3 \pm 0.35$ & Flexion \\
28 & 744.8 & $22.6 \pm 0.45$ & Post-flexion \\
\hline
\end{tabular}

flexion of the notochord (Fig. 1e). Finally, the hypural elements 4, 5 and 6 appeared between 18 and 20 dah (13.6 $\mathrm{mm} \mathrm{SL}$ ) in post-flexion larvae (Fig. 1f).

The first caudal fin rays were observed in relation with the H 2 and H 3 development, while at 28 dah (22.6 $\mathrm{mm} \mathrm{SL}$ ) the caudal fin rays development was complete (Table I), with 9 and 10 rays in ventral and dorsal lobe, respectively. Thus, the dorsal lobe was formed by the H 3-6 +10 principal rays (1 simple segmented ray and the remaining 9 segmented and branched) and 8 simple secondary rays; while the ventral lobe was composed by the $\mathrm{PH}$, the $\mathrm{H} 1$ and $2+9$ principal rays (8 segmented and branched and a single segmented ray) and 6 simple secondary rays. By this time (28 dah), all rays were found ossified. All epurals were evident as cartilaginous elements dorsally to the notochord and distally to the neural arches, remaining unossified until 25 dah. The central ural complex (CUC) appeared at 18 dah and was constituted by the fusion of three bony structures, the center preural 1 and the ural 1 and 2 (Fig. 1g).

\section{DISCUSSION}

The data presented in this work complement the previous knowledge on the embryonic development of $P$. lineatus (Botta et al.; Nakatani et al., 2001; Sverlij et al.) becoming the first description of chondrification and ossification stages for this species under controlled conditions.

According to Sverlij et al. and Nakatani et al. (2001), the larval period in $P$. lineatus starts from vitelline larvae, with approximately $4 \mathrm{~mm}$ in length, to the end of the postflexion stage, with 22-28 mm in length. In the present study a similar situation was demonstrated while the vitelline larvae presented $4.6 \mathrm{~mm}$ average length, obtaining $22.6 \mathrm{~mm}$ of total length and complete development of the caudal skeleton in post-flexion stage. Under culture conditions previously fixed in this work, a range of 35 to 38 vertebrae was counted, in comparison to that (37 and 38 vertebrae) reported by Roberts (1973) in Prochilodus specimens. According to Boglione et al. (2001), the meristic features present high variability in hatcheries when compared to those in wild groups. This difference can be attributed to the high variability of osteological development stages that presented fish as result of the interaction between genetic and environmental factors (Boglione et al.; Cardoso et al., 2004).

In the present study, notochord flexion started between 6-8 dah and finished at 18-20 dah with the complete development of the caudal skeleton. It was composed by six hypurals, one parahipural, the central ural complex, the epurals and a distribution of $10+9$ rays in the dorsal and ventral lobe of the caudal fin, respectively. In general, these observations agreed with Roberts and Sverlij et al. studies, except for the difficulty to recognized the presence of an urostile and two uroneurals, as described for Prochilodontidae family by the former. The complete development of the caudal skeleton is an event that provides great driving force in the caudal part of the body (Kendall et $a l$.), allowing to perform vital functions for larvae survival (Matsuoka, 1987). In natural environments, the optimal development of the locomotor system favors the feeding and helps to avoid predation (Koumoundouros et al., 2001). Although under intensive larviculture systems all conditions are controlled, deformations of the caudal fin are often presented as the most frequent alteration (Koumoundouros et al., 2001). This causes a negative effect on fish productivity due to the morphological alterations reached at commercialization stage. Finally, the economic value of the final product decreased (Boglione et al.; Fernández et al., 2008).

This paper describes, for the first time, the development of the vertebral column and caudal skeleton in sabalo larvae under culture conditions as being similar to that described in other teleostean fishes with some peculiarities that differentiate it from other groups (Hernández et al., 2012). Furthermore, this information represented an important contribution to the morphology of $P$. lineatus and provides the basis for future studies of skeletal 
malformations associated with larviculture systems and nutrition (Koumoundouros et al., 1999; Kuzir et al., 2009). We also provide relevant results aiming the definition of feeding strategies that may decrease the incidence of bone malformations during specific time-windows, associated with levels of certain nutrients in the diet that affect normal physiological processes during skeletogenesis phase (Fernández et al.; Darias et al., 2011).

HERNÁNDEZ, D. R.; OLIVERA, C.; SANTINÓN, J. J.; RUIZ DIAZ F. J. \& SÁNCHEZ, S. Desarrollo de la columna vertebral y del esqueleto caudal en larvas de Prochilodus lineatus en condiciones de larvicultura intensiva. Int. J. Morphol., 34(1):143-148, 2016.

RESUMEN: Se describe el desarrollo osteológico de la columna vertebral y del esqueleto caudal en larvas de sábalo (Prochilodus lineatus) bajo condiciones controladas hasta los 30 días posteriores a la eclosión (dpe). El inicio de la formación de la columna vertebral fue observado entre los 10-12 dpe (8,3 mm de longitud estándar, LE) con la aparición de los primeros procesos neurales, hemales y cuerpos vertebrales pre-caudales. La osificación de la columna vertebral ocurrió en sentido cráneo-caudal y fue completa a los 28 dpe (22,6 mm LE). El esqueleto caudal inició su desarrollo entre los 6 y 8 dpe con la formación de los hipurales (H), parahipural (PH) y los radios caudales principales y secundarios. Los $\mathrm{H} 1$ al 3 se formaron como primordios cartilaginosos en la cara ventral de la porción distal de la notocorda, mientras que posteriormente se formaron los $\mathrm{H} 4$ al 6 y el PH. Los primeros radios de la aleta caudal fueron observados en correspondencia con la formación de los $\mathrm{H} 2$ y 3, mientras que a los 28 dpe se observó la completa formación de los mismos, existiendo 10 radios en el lóbulo dorsal y 9 en el lóbulo ventral. Los epurales, en número de tres, fueron evidentes como elementos cartilaginosos en dorsal de la notocorda y distalmente a los arcos neurales, permaneciendo sin osificarse hasta los 25 dpe. El complejo centro ural se constituyó por la fusión de tres estructuras, el centro preural 1, el ural 1 y 2 . El desarrollo de la columna vertebral y del esqueleto caudal muestran patrones similares a los descriptos en otros teleósteos.

PALABRAS CLAVE: Prochilodus lineatus; Larvicultura; Desarrollo osteológico.

\section{REFERENCES}

Bailey, K. M. \& Houde, E. D. Predation on eggs and larvae of marine fishes and the recruitment problem. Adv. Mar. Biol., 25:1-83, 1989 .

Balon, E. K. Reflections on some decisive events in the early life of fishes. Trans. Am. Fish. Soc., 113(2):178-85, 1984.

Boglione, C.; Gagliardi, F.; Scardi, M. \& Cataudella, S. Skeletal descriptors and quality assessment in larvae and post-larvae of wild-caught and hatchery-reared gilthead sea bream (Sparus aurata L. 1758). Aquaculture, 192:1-22, 2001.

Botta, P.; Sciara, A.; Arranz, S.; Murgas, L. D. S.; Pereira, G. J. M. \& Oberlender, G. Estudio del desarrollo embrionario del sábalo (Prochilodus lineatus). Arch. Med. Vet., 42(2):109-14, 2010.

Cardoso, A. P.; Radünz Neto, J.; dos Santos Meideiros, T.; Knöpker, M. A. \& Lazzari, R. Criação de larvas de jundiá (Rhamdia quelen) alimentadas com rações granuladas contendo fígados ou hidrolisados. Acta Sci. Anim. Sci. (Maringá), 26(4):457$62,2004$.

Çoban, D.; Suzer, C.; Kamaci, H. O.; Saka, S . \& Firat, K. Early osteological development of the fins in the hatchery-reared red porgy, Pagrus pagrus (L. 1758). J. Appl. Ichthyol., 25(1):26-32, 2009.

Croux, M. J. P. Comportamiento y crecimiento de Prochilodus lineatus (Pisces, Curimatidae) en condiciones controladas. Rev. Asoc. Cienc. Nat. Litoral, 23(1-2):9-20, 1992.
Dahlberg, M. D. A review of survival rates of fish eggs and larvae in relation to impact assessments. Mar. Fish. Rev., 41:1-12, 1979.

Darias, M. J.; Mazurais, D.; Koumoundouros, G.; Le Gall, M. M.; Huelvan, C.; Desbruyeres, E.; Quazuguel, P.; Cahu, C. L. \& Zambonino-Infante, J. L. Imbalanced dietary ascorbic acid alters molecular pathways involved in skeletogenesis of developing European sea bass (Dicentrarchus labrax). Comp. Biochem. Physiol. A Mol. Integr. Physiol., 159(1):46-55, 2011.

Domitrovic, H. A. Histología del tracto digestivo del sábalo (Prochilodus platensis, Holmberg, 1880, Pisces Prochilodontidae). Physis, 41:57-67, 1983.

Fernández, I.; Hontoria, F.; Ortiz-Delgado, J. B.; Kotzamanis, Y.; Estévez, A.; Zambonino-Infante, J. L. \& Gisbert, E. Larval performance and skeletal deformities in farmed gilthead sea bream (Sparus aurata) fed with graded levels of Vitamin A enriched rotifers (Brachionus plicatilis). Aquaculture, 283(14):102-15, 2008.

Fuentes, C. M. Deriva de larvas de sábalo, Prochilodus lineatus, y otras especies de peces de interés comercial en el río Paraná Inferior. Thesis Doctoral. Buenos Aires, Universidad de Buenos Aires, 1998.

Furuya, V. R. B.; Hayashi, C.; Furuya, W. M.; Soares, C. M. \& Galdioli, E. M. Influência de plâncton, dieta artificial e sua combinação, sobre o crescimento e sobrevivência de larvas de curimbatá (Prochilodus lineatus). Acta Sci. Anim. Sci. (Maringá), 21(3):699-703, 1999. 
González, J.; Hernández, G.; Messia, O. \& Pérez, A. Extracto hipofisiario de Coporo (Prochilodus mariae) como agente inductor sustitutivo en la reproducción de su misma especie. Zootec. Trop., 28(1):25-32, 2010.

Hainfellner, P.; Souza, T. G.; Moreira, R. G.; Nakaghi, L. S. O. \& Batlouni, S. R. Gonadal steroids levels and vitellogenesis in the formation of oocytes in Prochilodus lineatus (Valenciennes) (Teleostei: Characiformes). Neotrop. Ichthyol., 10(3):601-12, 2012.

Hernández, D. R.; Casciotta, J. R.; Santinón, J. J.; Sánchez, S. \& Domitrovic, H. A. Ontogenic development of the vertebral column and caudal skeleton in rhamdia quelen larvae in larviculture intensive system. Int. J. Morphol., 30(4):1520-5, 2012.

Kendall, A. W. Jr.; Ahlstrom, E. H. \& Moser, H. G. Early life history stages of fishes and their characters. En: Moser, H. G.; Richards, W. J.; Cohen, D. M. \& Fahay, M. P. (Eds.). Ontogeny and systematics of fishes. Lawrence, American Society of Ichthyologists and Herpetologists Special Pub. No. 1, 1984. pp.11-23.

Koumoundouros, G.; Divanach, P. \& Kentouri, M. Osteological development of the vertebral column and of the caudal complex in Dentex dentex. J. Fish Biol., 54(2):424-36, 1999.

Koumoundouros, G.; Divanach, P. \& Kentouri, M. The effect of rearing conditions on development of saddleback syndrome and caudal fin deformities in Dentex dentex (L.). Aquaculture, 200(3-4):285-304, 2001.

Kuzir, S.; Kozaric', Z.; Gjurcevic', E.; Bazdaric', B. \& Petrinec, Z. Osteological development of the garfish (Belone belone) larvae. Anat. Histol. Embryol., 38(5):351-4, 2009.

Lall, S. P. \& Lewis-McCrea, L. M. Role of nutrients in skeletal metabolism and pathology in fish - An overview. Aquaculture, 267(1-4):3-19, 2007.

Lewis, L. M. \& Lall, S. P. Development of the axial skeleton and skeletal abnormalities of Atlantic halibut (Hippoglossus hippoglossus) from first feeding through metamorphosis. Aquaculture, 257(1-4):124-35, 2006.

Matsuoka, M. Development of the skeletal tissues and skeletal muscles in the red sea bream [Pagrus major]. Bull. Seikai Reg. Fish. Res. Lab., 65:1-114, 1987.

Nakatani, K.; Agostinho, A. A.; Baumgartner, G.; Bialetzki, A.; Sanches, P. V.; Makrakis, M. C. \& Pavanelli, C. S. Ovos e larvas de peixes de água doce: desenvolvimento e manual de identificação. Maringá, Eduem, 2001. p.378.

Roberts, T. R. Osteology and relationships of the Prochilodontidae, a South American family of Characoid fishes. Bull. Mus. Comp. Zool., 145(4):213-35, 1973.
Sverlij, S. B.; Espinach Ros, A. \& Orti, G. Sinopsis de los datos biológicos y pesqueros del Sabalo Prochilodus lineatus (valenciennes, 1847). FAO Sinopsis Sobre La Pesca No 154. Roma, FAO, 1993. pp.1-64.

Taylor, W. R. \& Van Dyke, G. C. Revised procedures for staining and clearing small fishes and other vertebrates for bone and cartilage study. Cybium, 9(2):107-19, 1985.

Welcomme, R. L. River Fisheries. F. A. O. Fish. Tech. Pap. 262, 1985.

Woynarovich, E. \& Horváth, L. A propagação artificial de peixes de águas tropicais: manual de extensão. Brasília, FAO/ CODEVASF/CNPq, 1983.

Correspondence to:

Dr. David R. Hernández

Cátedra de Histología y Embriología

Instituto de Ictiología del Nordeste

Facultad de Ciencias Veterinarias

Universidad Nacional del Nordeste

Sgto Cabral 2139

Corrientes

ARGENTINA

Tel: +0054 3794 425753. Interno 171 -

Email: darhernandez19@hotmail.com

Received: 18-08-2015

Accepted: 20-10-2015 